\title{
PENGARUH EARNING PER SHARE, FIRM SIZE, DAN SALES GROWTHTERHADAP DIVIDEND PAYOUT RATIO (STUDI EMPIRIS PADA PERUSAHAAN MANUFAKTUR SEKTOR MAKANAN DAN MINUMANYANG TERDAFTAR DI BURSA EFEK INDONESIA (TAHUN 2014 SAMPAI TAHUN 2018
}

\author{
Siti Nurlatifah \\ Fakultas Ekonomi Universitas Krisnadwipayana \\ Jalan Unkris Jatiwaringin Jakarta Timur \\ e-mail : : ifa.latifah81@yahoo.com
}

\begin{abstract}
The purpose of this study is to determine the effect of earnings per share, firm size, and sales growth on the dividend payout ratio. The population used is the food and beverage sector manufacturing companies listed on the Indonesia Stock Exchange in 2014-2018 as many as 26 and the sample in this study were 7 companies determined through purposive sampling. This study uses simple regression analysis techniques and multiple regression and uses SPSS 25 program analysis tools. The results of the t test (partial) show that earning per share variable has a negative and not significant effect on dividend payout ratio. Firm size variable has a positive and significant effect on dividend payout ratio. Sales growth variable has positive and significant effect on dividend payot ratio. The $F$ (simultaneous) test results show that the earnings per share, firm size, and sales growth variables simultaneously have a significant effect on the dividend payout ratio.
\end{abstract}

Keywords :Earning Per Share, Firm Size, Sales Growth, and Dividend Payout Rasio

\section{PENDAHULUAN}

Pasar modal (capital market) merupakan pasar untuk berbagai instrumen keuangan jangka panjang dalam bentuk ekuitas dan hutang yang jatuh tempo lebih dari satu tahun. Dalam aktivitas di pasar modal, para investor memiliki harapan dari investasi yang dilakukannya, yaitu yang berupa capital gain dan dividen.

Dividen adalah pembagian keuntungan yang diberikan penerbit saham atas keuntungan yang dihasilkan perusahaan. Dividen yang dibagikan perusahaan dapat berupa dividen tunai (cash dividend) dan dividen saham (stock dividend). Capital gain merupakan selisih antara harga beli dan harga jual. Capital gain terbentuk dengan adanya aktivitas perdagangan saham di pasar sekunder. Umumnya investor dengan orientasi jangka pendek mengejar keuntungan melalui capital gain.
Dalam hubungannya dengan pendapatan dividen, para investor umumnya menginginkan pembagian dividen yang relatif stabil, karena dengan stabilitas dividen dapat meningkatkan kepercayaan investor terhadap perusahaan sehingga mengurangi ketidakpastian investor dalam menanamkan dananya kedalam perusahaan. Bagi perusahaan, pilihan untuk membagikan laba dalam bentuk deviden akan mengurangi sumber dana internalnya, sebaliknya jika perusahaan menahan labanya dalam bentuk laba ditahan maka kemampuan pembentukan dana internalnya akan semakin besar yang dapat digunakan untuk membiayai aktivitas perusahaan sehingga mengurangi ketergantungan perusahaan terhadap dana eksternal dan sekaligus akan memperkecil resiko perusahaan.

Besar kecilnya dividend payout ratio tergantung pada kebijakan dividen yang 
Electronic ISSN : 2655 - 9919

DOI: http://dx.doi.org/10.35137/jabk.v8i2.539 ditetapkan oleh masing-masing suatu perusahaan. Secara umum penetapan kebijakan dividen dipengaruhi oleh berbagai faktor. Faktor-faktor yang mempengaruhi kebijakan dividen diantaranya adalah penghasilan per saham, ukuran perusahaan, dan pertumbuhan penjualan perusahaan.

Dividend Payout Ratio merupakan perbandingan dividen dengan laba bersih yang diperoleh. Semakin besar dividend payout ratio yang ditetapkan perusahaan berarti semakin besar bagian keuntungan perusahaan yang dibayarkan sebagai dividen. Semakin besar dividend payout ratio maka akan semakin kecil laba ditahan, laba ditahan yang kecil akan menghambat tingkat pertumbuhan perusahaan. Sebaliknya, apabila laba ditahan semakin besar maka dividend payout ratio akan semakin kecil, kecilnya nilai dividend payout ratio dapat menimbulkan sinyal buruk dan reaksi yang buruk dari para pemegang saham.

Earnings Per Share(EPS) merupakan rasio keuangan yang mengukur jumlah laba bersih yang diperoleh per lembar saham yang beredar. Earnings Per Share ini mempresentasikan jumlah uang yang akan diterima oleh para pemegang saham atas setiap lembar saham yang dimilikinya saat pembagian keuntungan saham yang beredar pada akhir tahun. Analisis ini dimaksudkan untuk mengukur seberapa besar keuntungan per lembar saham yang menjadi hak pemilik saham, sehingga jika keuntungan per lembar saham tinggi maka para investor akan tertarik menginvestasikan uangnya dengan membeli saham.

Firm Size merupakan ukuran perusahaan yang menggambarkan besar kecilnya suatu perusahaan yang ditunjukkan oleh total aktiva, jumlah penjualan, rata-rata total penjualan aset, dan rata-rata total aktiva. Jika perusahaan memiliki total aset yang besar, pihak manajemen lebih leluasa
Jurnal Akuntansi dan Bisnis Krisnadwipayana Volume 8 No. 2 (Mei - Agustus) 2021

dalam mempergunakan aset yang ada diperusahaan tersebut.

Sales Growth digunakan untuk mengukur seberapa besar tingkat pertumbuhan pada suatu perusahaan (Fahmi, 2014:82). Pertumbuhan atas penjualan merupakan indikator penting dari penerimaan pasar dari produk dan/atau jasa perusahaan tersebut, dimana pendapatan yang dihasilkan dari penjualan akan dapat digunakan untuk mengukur tingkat pertumbuhan penjualan. Pertumbuhan penjualan tinggi, maka akan mencerminkan pendapatan perusahaan yang juga meningkat. Laju pertumbuhan suatu perusahaan akan mempengaruhi kemampuan mempertahankan keuntungan dalam menandai kesempatan-kesempatan yang akan datang.

Berikut ini disajikan grafik mengenai pengaruh Earning Per Share, Firm Size, dan Sales Growth Terhadap Dividend Payout Ratio pada perusahaan manufaktur sektor makanan dan minuman tahun 20142018 yang dapat dilihat dari grafik dibawah ini:

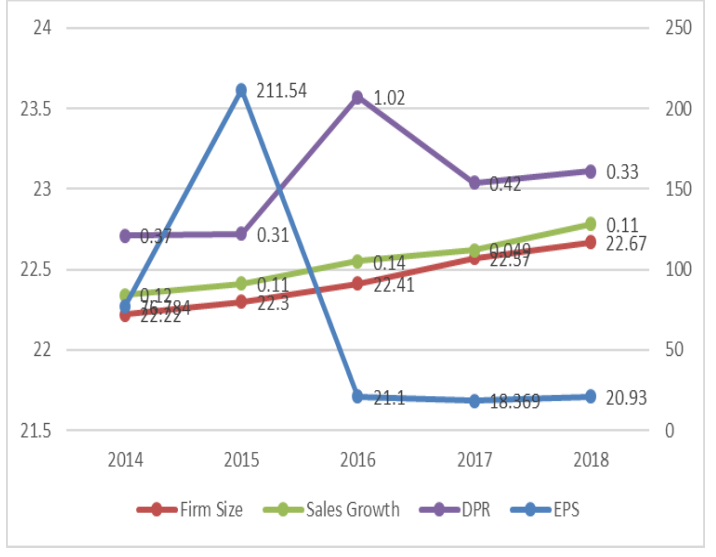

Gambar 1. Pengaruh EPS, Firm Size, dan Sales Growth Terhadap Dividend Payout Ratioperusahaan manufaktur sektor makanan dan minuman tahun 2014-2018.

Berdasarkan grafik earning per share mengalami fluktuasi yaitu pada tahun 2014 
DOI: http://dx.doi.org/10.35137/jabk.v8i2.539 sebesar 76,784 atau $76,784 \%$, kemudian pada tahun 2015 naik menjadi 211,54\%, lalu pada tahun 2016 turun menjadi 21,10\%, kemudian pada tahun 2017 turun menjadi $18,369 \%$ dan meningkat kembali pada tahun 2018 sebesar 20,93\%. Peningkatan tersebut dikarenakan terjadinya banyak investor yang membeli saham perusahaan tersebut sehingga menyebabkan harga saham menjadi tinggi.

Berdasarkan grafik firm size dari tahun ke tahun terjadi peningkatan pada tahun 2014 sebesar $22,22 \%$ lalu pada tahun 2015 sebesar 22,30\%, pada tahun 2016 meningkat kembali sebesar $22,41 \%$, lalu pada tahun 2017 sebesar 22,57\%, kemudian meningkat kembali pada tahun 2018 sebesar $22,67 \%$. Semakin tinggi ukuran perusahaan menunjukkan bahwa total aset akan meningkat dan kemungkinan akan memberikan pembayaran dividen yang lebih besar.

Berdasarkan grafik sales growth pada tahun 2014 sebesar $0,12 \%$ lalu pada tahun 2015 mengalami penurunan sebesar $0,11 \%$, kemudian mengalami peningkatan pada tahun 2016 sebesar $0,14 \%$, lalu pada tahun 2017 menurun sebesar $0,049 \%$ dan tahun 2018 meningkat kembali sebesar $0,11 \%$. Jika pertumbuhan penjualan menurun maka kebutuhan dana pun akan menurun.

Berdasarkan grafik dividend payout ratio pada tahun 2014 sebesar 0,37 atau $37 \%$, kemudian mengalami penurunan pada tahun 2015 sebesar 0,31 atau 31\%, lalu meningkat kembali pada tahun 2016 sebesar 1,02 atau $102 \%$, terjadi penurunan pada tahun 2017 sebesar 0,42 atau $42 \%$, dan pada tahun 2018 menurun kembali sebesar 0,33 atau $33 \%$. Rata-rata jumlah dividen mengalami penurunan dan kenaikan, ini menunjukkan penurunan persentase dividend payout ratio yang terjadi karena beberapa emiten mengalami penurunan laba bersih sehingga menurun nya dividen per share yang dibagikan serta dividend payout
Printed ISSN : $2406-7415$

Electronic ISSN : 2655 - 9919

Jurnal Akuntansi dan Bisnis Krisnadwipayana Volume 8 No. 2 (Mei - Agustus) 2021

ratio juga mengalami penurunan dan menunjukkan kenaikan persentase dividend payout ratio bahwa emiten ingin memuaskan para investor sehingga akan menaikkan permintaan saham.

Beberapa peneliti sebelumnya telah menemukan beberapa yang mempengaruhi dividend payout ratio. Muammar Hanif dan Bustaman (2017) meneliti mengenai pengaruh return on asset dan earning per share yang berpengaruh positif signifikan terhadap dividend payout ratio, sedangkan debt to equity dan firm size tidak berpengaruh terhadap dividend payout ratio pada perusahaan manufaktur yang terdaftar di Bursa Efek Indonesia. Sedangkan Maidiana Astuti dan Muhammadinah (2018) yang melakukan penelitian mengenai pengaruh sales growth dan profitabilitas secara bersama-sama berpengaruh dan signifikan terhadap variabel dividend payout ratio pada perusahaan Perbankan yang terdaftar di Bursa Efek Indonesia.

Jurica Lucyanda dan Lilyana (2018) yang melakukan penelitian mengenai pengaruh free cash flow berpengaruh positif terhadap dividend payout ratio, persentase kepemilikan institusional berpengaruh negatif terhadap dividend payout ratio, dan kepemilikan keluarga dan persentase kepemilikan asing tidak berpengaruh secara signifikan terhadap dividend payout ratio.Sedangkan Kevin dkk (2019) melakukan penelitian mengenai pengaruh free cash flow,leverage, net profit margin dan pertumbuhan perusahaan terhadap dividend payout ratio, hasilnya menunjukkan tidak berpengaruh signifikan terhadap dividend payout ratio.

Berdasarkan uraian tersebut, hasil penelitian sebelumnya yang tidak konsisten, maka penulis akan melakukan penelitian yang berjudul "Pengaruh Earning Per Share, Firm Size,dan Sales Growth Terhadap Dividend Payout Ratio (Studi 
DOI: http://dx.doi.org/10.35137/jabk.v8i2.539

Pada Perusahaan Manufaktur Sektor

Makanan dan Minuman Yang Terdaftar Di

Bursa Efek Indonesia Tahun 2014-2018)".

\section{LANDASAN TEORI}

\section{Manajemen}

\section{a. Arti Manajemen}

Pengertian manajemen pada umumnya dapat didefinisikan sebagai sebuah proses dalam rangka untuk mencapai suatu tujuan organisasi dengan cara bekerja secara bersama sama dengan orang-orang dan sumber daya yang dimiliki organisasi.Adapun arti manajemen menurut beberapa para ahli yaitu sebagai berikut:

Menurut Henry Fayol:Manajemen mengandung gagasan 5 fungsi utama yaitu, merancang, mengorganisasi, memerintah, mengoordinasi, dan mengendalikan.

Menurut Ricky W. Griffin:Manajemen sebagai sebuah proses perencanaan, pengorganisasian, pengkoordinasian, dan pengontrolan sumber daya untuk mencapai sasaran (goals) secara efektif dan efesien. Efektif berarti bahwa tujuan dapat dicapai sesuai dengan perencanaan, sementara efisien berarti bahwa tugas yang ada dilaksanakan secara benar, terorganisir, dan sesuai dengan jadwal.

Menurut G. R. Terry:Manajemen adalah suatu proses atau kerangka kerja, yang melibatkan bimbingan atau pengarahan suatu kelompok orang-orang ke arah tujuantujuan organisasional atau maksud-maksud yang nyata.

b. Fungsi Manajemen

Menurut Henry Fayol dalam bukunya yang berjudul General and Industrial Manajement dijelaskan 5 fungsimanajemen, yaitu: Planning(perencanaan), Organizing(pengorganisasian),
Printed ISSN : $2406-7415$

Electronic ISSN : 2655 - 9919

Jurnal Akuntansi dan Bisnis Krisnadwipayana Volume 8 No. 2 (Mei - Agustus) 2021

Commanding(pemberian perintah), dan

Controlling(pengendalian).

Berbeda lagi dengan pendapat G. R. Terry dalam bukunya yang berjudul Principle of manajement dijelaskan 5 fungsi manajemen, yaitu: Planning, Organizing, Actuating, dan Controlling, (perencanaan, pengorganisasian, pelaksanaan, dan pengendalian), dan masih banyak lagi menurut para ahli yang lain tentang fungsi manajemen.

Dari fungsi-fungsi manajemen tersebut pada dasarnya memiliki kesamaan yang harus dilaksanakan oleh setiap manajer secara berurutan supaya proses manajemen itu diterapkan secara baik. Adapun fungsi manajemen yang utama lebih dikenal dengan (POAC) Perencanaan (planning), Pengorganisasian (organizing), Penggerakan (actuating), dan Pengawasan (controlling).

\section{Manajemen Keuangan}

MenurutSartono (2011) istilah manajemen keuangan dapat diartikan sebagai manajemen dana baik yang berkaitan dengan pengalokasian dana dalam berbagai bentuk investasi secara efektif maupun usaha pengumpulan dana untuk pembiayaan investasi atau pembelanjaan secara efisien.

Pelaksana dari manajemen keuangan adalah manajer keuangan. Meskipun fungsi seorang manajer keuangan setiap organisasi belum tentu sama, namun pada prinsipnya fungsi utama seorang manajer keuangan adalah merencanakan, mencari, dan memanfaatkan dengan berbagai cara untuk memaksimumkan efisiensi (daya guna) dari operasi-operasi perusahaan.

Manajemen keuangan yang efisien membutuhkan tujuan dan sasaran yang digunakan sebagai standar dalam memberikan penilaian keefisienan keputusan keuangan. Untuk dapat mengambil keputusan-keputusan 
DOI: http://dx.doi.org/10.35137/jabk.v8i2.539

keuangan yang benar, manajer keuangan perlu menentukan tujuan yang harus dicapai.

Tujuan manajemen keuangan adalah meningkatkan kemakmuran para pemegang saham atau pemilik. Kemakmuran para pemegang saham diperlihatkan dalam wujud semakin tingginya harga saham.

\section{Laporan Keuangan}

1) Pengertian Laporan Keuangan

Laporan keuangan atau dalam Bahasa Inggris disebut financial statement merupakan hasil akhir dari suatu proses pencatatan kegiatan transaksi keuangan dalam sebuah suatu perusahaan yang menggambarkan keadaan keuangan perusahaan itu di satu periode akuntansi serta merupakan gambaran umum tentang kinerja suatu perusahaan.

Munawir (2010) mengatakan bahwa laporan keuangan pada umumnya terdiri atas neraca serta perhitungan laba rugi dan juga perubahan ekuitas. Neraca ini menunjukkan sejumlah aset, kewajiban dan juga ekuitas dari sebuah perusahaan dalam periode tertentu. Sementara laba rugi menggambarkan berbagai hasil dan juga beban perusahaan yang berhasil diraih.

Menurut Irham Fahmi (2012), Laporan Keuangan adalah suatu informasi yang menyatakan kondisi perusahaan yang selanjutnya akan menjadi suatu informasi yang menggambarkan tentang kinerja suatu perusahaan.

Berdasarkan pengertian di atas, maka dapat ditarik kesimpulan bahwa:

1. Informasi laporan keuangan sangat diperlukan oleh para pengguna guna mengevaluasi serta membandingkan dampak dari kebijakan ekonomi yang sebelumnya sudah dipakai,

2. Laporan keuangan sangat dibutuhkan untuk meramal serta menilai apakah di masa sekarang dan akan datang perusahaan akan mampu mendatangkan
Printed ISSN : $2406-7415$

Electronic ISSN : 2655 - 9919

Jurnal Akuntansi dan Bisnis Krisnadwipayana Volume 8 No. 2 (Mei - Agustus) 2021 keuntungan yang sama atau bahkan lebih, dan;

3. Informasi perubahan kedudukan keuangan juga bermanfaat dalam menilai kegiatan investasi, pendanaan serta operasi perusahaan dalam periode tertentu.

2) Bentuk dan Jenis Laporan Keuangan

Menurut Kasmir (2016), secara umum ada lima macam jenis laporan keuangan yang biasa disusun:

\section{Balance Sheet (Neraca)}

Balance sheet (neraca) merupakan laporan yang menunjukkan posisi keuangan perusahaan pada tanggal tertentu. Arti dari posisi keuangan dimaksudkan adalah posisi jumlah dan jenis aktivitas (harta) dan pasiva (kewajiban dan ekuitas) suatu perusahaan.

2. Income Statement (Laporan Laba Rugi) Income statement (laporan laba rugi) merupakan laporan keuangan yang menggambarkan hasil usaha perusahaan dalam suatu periode tertentu.

3. Laporan Perubahan Modal

Laporan perubahan modal merupakan laporan yang berisi jumlah dan jenis modal yang dimiliki pada saat ini. Kemudian, laporan ini juga menjelaskan perubahan modal dan sebab-sebab terjadinya perubahan modal di perusahaan.

4. Laporan Arus Kas

Laporan arus kas merupakan laporan yang menunjukkan arus kas masuk dan arus kas keluar di perusahaan.

5. Laporan Catatan Atas Laporan Keuangan

Laporan catatan atas laporan keuangan merupakan laporan yang dibuat berkaitan dengan laporan keuangan yang disajikan. Laporan ini memberikan informasi tentang 
DOI: http://dx.doi.org/10.35137/jabk.v8i2.539

penjelasan yang dianggap perlu atas laporan keuangan yang ada sehingga menjadi jelas sebab penyebabnya. Tujuannya adalah agar pengguna laporan keuangan dapat memahami jelas data keuangan.

\section{Arti Saham dan Jenis Saham}

Saham adalah dokumen berharga yang menunjukkan kepemilikan perusahaan. Jadi, ketika seseorang membeli saham perusahaan, orang itu memiliki hak untuk aset dan pendapatan perusahaan dengan sebagian dari saham yang dibeli.Menurut Darmadji dan Fakhruddin (2012) "Saham (stock) merupakan tanda penyertaan atau pemilikan seseorang atau badan dalam suatu perusahaan atau perseroan terbatas. Saham berwujud selembar kertas yang menerangkan bahwa pemilik kertas tersebut adalah pemilik perusahaan yang menerbitkan surat berharga tersebut".

Saham merupakan surat berharga yang paling populer dan dikenal luas di masyarakat. Menurut Darmadji dan Fakhruddin (2012), ada beberapa jenis saham yaitu:

1. Ditinjau dari segi kemampuan dalam hak tagih atau klaim, maka saham terbagi atas:

a. Saham biasa (common stock), yaitu merupakan saham yang menempatkan pemiliknya paling junior terhadap pembagian dividen, dan hak atas harta kekayaan perusahaan apabila perusahaan tersebut dilikuidasi.

b. Saham preferen (preferred stock), merupakan saham yang memiliki karakteristik gabungan antara obligasi dan saham biasa, karena bisa menghasilkan pendapatan tetap (seperti bunga obligasi), tetapi juga bisa tidak mendatangkan hasil seperti ini dikehendaki oleh investor.

2. Dilihat dari cara pemeliharaannya, saham dibedakan menjadi:

a. Saham atas unjuk (bearer stock), artinya pada saham tersebut tidak tertulis nama
Printed ISSN : $2406-7415$

Electronic ISSN : 2655 - 9919

Jurnal Akuntansi dan Bisnis Krisnadwipayana Volume 8 No. 2 (Mei - Agustus) 2021 pemiliknya, agar mudah dipindahtangankan dari satu investor ke investor lain.

b. Saham atas nama (registered stock), merupakan saham yang ditulis dengan jelas siapa pemiliknya, dan dimana cara peralihannya harus melalui prosedur tertentu.

3. Ditinjau dari kinerja perdagangannya, maka saham dapat dikategorikan menjadi:

a. Saham unggulan (blue-chip stock), yaitu saham biasa dari suatu perusahaan yang memiliki reputasi tinggi, sebagai leader di industri sejenis, memiliki pendapatan yang stabil dan konsisten dalam membayar dividen.

b. Saham pendapatan (income stock), yaitu saham biasa dari suatu emiten yang memiliki kemampuan membayar dividen lebih tinggi dari rata-rata dividen yang dibayarkan pada tahun sebelumnya.

c. Saham pertumbuhan (growth stock-well known), yaitu saham-saham dari emiten yang memiliki pertumbuhan pendapatan yang tinggi, sebagai leader di industri sejenis yang mempunyai reputasi tinggi. Selain itu terdapat juga growth stock lesser known, yaitu saham dari emiten yang tidak sebagai leader dalam industri namun memiliki ciri growth stock.

d. Saham spekulatif (speculative stock), yaitu saham suatu perusahaan yang tidak bisa secara konsisten memperoleh penghasilan yang tinggi di masa mendatang, meskipun belum pasti.

e. Saham sklikal (counter cyclical stock), yaitu saham yang tidak terpengaruh oleh kondisi ekonomi makro maupun situasi bisnis secara umum.

\section{Dividen}

a. Pengertian dividen

Pengertian dividen menurut Rudianto (2012) adalah: "Dividen adalah bagian laba 
Electronic ISSN : 2655 - 9919

DOI: http://dx.doi.org/10.35137/jabk.v8i2.539 usaha yang diperoleh perusahaan dan diberikan oleh perusahaan kepada pemegang sahamnya sebagai imbalan atas kesediaan mereka menanamkan hartanya dalam perusahaan".

Dividen dapat dibagi menjadi dua yaitu berupa uang tunai maupun saham. Dividen tunai (cash dividend) umumnya lebih menarik bagi pemegang saham dibandingkan dengan dividen saham (stock dividend). Yang perlu diperhatikan oleh pimpinan perusahaan sebelum membuat pengumuman adanya dividen kas yaitu apakah jumlah uang kas yang ada mencukupi untuk pembagian dividen tersebut. Terkait dengan dividen terdapat 3 tanggal penting, yaitu pengumuman, pencatatan, dan pembayaran atau pembagian.

b. Tujuan pembagian dividen adalah:

1) Untuk memaksimalkan kemakmuran para pemegang saham. Hal ini sesuai dengan tujuan para investor yang menanamkan modalnya di pasar modal untuk mendapatkan dividen.

2) Untuk menunjukkan tentang likuiditas perusahaan. Melalui pembagian dividen yang rutin, diharapkan kinerja perusahaan dimata investor cukup baik. Tidak sedikit perusahaan yang membagikan dividen tetap dengan tujuan untuk menunjukkan likuiditas suatu perusahaan sekalipun gejolak ekonomi terjadi, akan tetapi mampu memberikan hasil kepada para investor.

3) Pihak investor menilai risiko dividen lebih rendah dibandingkan dengan capital gain.

4) Untuk memenuhi kebutuhan para pemegang saham sebagai pendapatan tetap yang digunakan untuk keperluan konsumsi.

5) Dividen dapat digunakan sebagai alat komunikasi antar manajer dan para
Jurnal Akuntansi dan Bisnis Krisnadwipayana Volume 8 No. 2 (Mei - Agustus) 2021 pemegang saham. Informasi secara keseluruhan internal perusahaan sering tidak diketahui para pemegang saham. Oleh karenanya, melalui dividen, pertumbuhan serta prospek perusahaan dapat diketahui.

c. Teori Kebijakan Dividen

Kebijakan deviden merupakan suatu keputusan untuk menentukan berapa besarnya bagian dari perusahaan yang akan dibagikan kepada para pemegang saham, yang akan di investasikan kembali, dan ditahan dalam perusahaan hingga dicapai kebijakan dividen yang optimal.

Kebijakan deviden yang optimal memiliki keseimbangan antara deviden saat ini dan pertumbuhan perusahaan dimasa yang akan datang.

Bahwa dalam kebijakan dividen terdapat lima teori dari preferensi investor yaitu:

1. Deviden Irrelevance Theory (Ketidak Relevanan Deviden)

Teori ini menyatakan bahwa kebijakan dividen perusahaan tidak mempunyai pengaruh, baik terhadap nilai perusahaan maupun biaya modalnya. Pendukung utama teori ketidak relevanan dividen (dividends irrelevance theory) ini yaitu suatu nilai perusahaan tidak ditentukan oleh besar kecilnya dividend payout ratio, tetapi di tentukan oleh besarnya laba bersih sebelum pajak dan risiko bisnisnya.

2. Bird in the hand Theory (Deviden yang Relevan)

Bird in the hand adalah teori yang menjelaskan bahwa lebih baik satu burung di tangan daripada seribu burung diudara, karena investor lebih menyukai pembagian deviden daripada capital again.

3. Tax Preference Theory (Teori Preferensi Pajak)

Suatu teori yang menyatakan menyatakan bahwa karena adanya 
Electronic ISSN : 2655 - 9919

DOI: http://dx.doi.org/10.35137/jabk.v8i2.539

pajak terhadap keuntungan dividen dan capital gains maka para investor lebih menyukai capital gains karena dapat menunda pembayaran pajak.

4. Information Content or Signaling Hypothesis (Konten Informasi atau Hipotesis Signaling)

Dalam teori ini Modigliani \& Miller menyatakan bahwa pengumuman pembayaran deviden adalah signal bagi investor kenaikan deviden yang diatas kenaikan normal merupakan suatu sinyal bagi para investor bahwa manajemen perusahaan meramalkan suatu penghasilan yang baik dimasa yang akan datang. Namun sebaliknya suatu penurunan normal diyakini investor sebagai suatu sinyal bahwa perusahaan akan berada dalam masa sulit dimasa mendatang.

5. Clientele Effect

Menyatakan bahwa pemegang saham yang berbeda akan memiliki preferensi yang berbeda terhadap kebijakan dividen perusahaan. Kelompok investor yang membutuhkan penghasilan saat ini lebih menyukai suatu Dividend Payout Ratio yang tinggi, sebaliknya kelompok investor yang tidak begitu membutuhkan uang saat ini lebih senang jika perusahaan menahan sebagian besar laba bersih perusahaan.

d. Faktor-Faktor Yang Mempengaruhi Kebijakan Dividen

Berikut ini, akan dibahas faktor-faktor yang biasanya harus (dan seharusnya) dianalisis perusahaan ketika membuat keputusan kebijakan dividen, yaitu:

1) Aturan-aturan Hukum

Berbagai aturan hukum yang dibahas dalam membuat batasan hukum yang memungkinkan di bawah ini penting kebijakan dividen akhir perusahaan dapat berjalan.
Jurnal Akuntansi dan Bisnis Krisnadwipayana Volume 8 No. 2 (Mei - Agustus) 2021

2) Kebutuhan Pendanaan Perusahaan Intinya adalah menentukan arus kas dan posisi kas perusahaan yang akan terjadi di tengah ketiadaan perubahan kebijakan dividen.

3) Likuiditas

Likuiditas perusahaan merupakan pertimbangan utama dalam banyak keputusan dividen karena dividen menunjukkan arus kas keluar, semakin besar posisi kas dan keseluruhan likuiditas perusahaan maka semakin besar kemampuan perusahaan untuk membayar dividen

4) Kemampuan Untuk Meminjam

Semakin besar kemampuan perusahaan untuk meminjam maka semakin besar pula fleksibilitas untuk meminjam sehingga perusahaan tidak perlu khawatir dengan pengaruh pembayaran dividen kas terhadap likuiditasnya.

5) Batasan-batasan dalam Kontrak Utang Biasanya syarat perjanjian utang dinyatakan sebagai persentase maksimum laba ditahan kumulatif dalam perusahaan, larangan ini otomatis mempengaruhi pembayaran dividen perusahaan.

6) Pengendalian

Apabila perusahaan dalam kondisi akan diakuisisi pembayaran dividen yang rendah akan menguntungkan pihak luar yang sedang mencoba mendapatkan kendali.

\section{Earning Per Share}

Earning per share adalah jumlah pendapatan yang diperoleh dalam satu periode untuk tiap lembar saham yang beredar. Sedangkan earning per share bisa disebut juga sebagai pendapatan bersih per lembar saham yaitu jumlah pendapatan yang didapat dari tiaptiap lembar saham biasa yang disetorkan perusahaan.Kenaikan earning per share berarti perusahaan sedang dalam tahap pertumbuhan atau kondisi keuangannya sedang mengalami 
Printed ISSN : $2406-7415$

Electronic ISSN : 2655 - 9919

DOI: http://dx.doi.org/10.35137/jabk.v8i2.539

peningkatan dalam penjualan dan laba, atau dengan kata lain semakin besar earning per share menandakan kemampuan perusahaan dalam menghasilkan keuntungan bersih setiap lembar saham.

Maksimalisasi laba (profit maximization) sering dipandang sebagai tujuan yang tepat bagi sebuah perusahaan. Namun, hal ini sebenarnya memiliki kelemahan karena dengan hanya menerbitkan saham dan menggunakan hasilnya untuk berinvestasi dalam sekuritas yang tidak berisiko laba dapat meningkat. Hal tersebut bagi kebanyakan perusahaan mengakibatkan jatuhnya laba per saham (EPS), sehingga ukuran yang lebih tepat adalah memaksimalkan earning per share.

Earning per share adalah termasuk salah satu rasio pasar rasio pasar pada dasarnya mengukur kemampuan manajemen dalam menciptakan nilai pasar yang melampaui pengeluaran investasi. Rasio ini merupakan pengukuran yang paling lengkap mengenai prestasi perusahaan dan berkaitan langsung dengan tujuan memaksimalkan nilai perusahaan dan kekayaan para pemegang saham.

Alasan menggunakan Earning Per Share menurut Eduardus Tandelilin (2010) menerangkan bahwa Earning Per Share diutamakan dalam analisis perusahaan karena tiga alasan:

1. Laba Per Saham biasa dipakai untuk mengestimasi nilai intrinsik saham.

2. Dividen yang dibayarkan perusahaan pada dasarnya dibayarkan dari earning (laba).

3. Adanya hubungan antara perubahan earning (laba) dengan perubahan harga saham.

Dengan kata lain bila perusahaan ingin meningkatkan kesejahteraan para pemegang sahamnya, maka harus memusatkan perhatiannya pada laba per lembar saham (EPS), sehingga jika Earning Per Share suatu perusahaan tidak memenuhi harapan para pemegang sahamnya, maka keadaan ini akan berdampak pada harga saham yang rendah. Penjelasan di atas dapat diketahui bahwa
Jurnal Akuntansi dan Bisnis Krisnadwipayana Volume 8 No. 2 (Mei - Agustus) 2021 hubungan antara laba per lembar saham dengan harga saham sangat erat.

Menurut Tandelilin (2010) secara matematis Earning Per Share dapat dirumuskan sebagai berikut:

$$
\operatorname{EPS}=\frac{\text { Earring Aftar } T a x}{\text { Jumlah Saham Bargdar }}
$$

Keterangan:

EPS = Earning Per Share

Earning After Tax $=$ Laba bersih setelah pajak

\section{Firm Size}

Peraturan Otoritas Jasa Keuangan Nomor 53/POJK.04/2017 mengatur tentang klasifikasi perusahaan aset skala kecil dan menengah, termasuk batasan pendanaan modal perusahaan.

Firm size atau ukuran perusahaan adalah suatu skala dimana dapat diklasifikasikan besar kecil perusahaan menurut berbagai cara, dimana ukuran perusahaan hanya terbagi dalam 3 kategori yaitu perusahaan besar (large firm), perusahaan menengah (medium size), dan perusahaan kecil (small firm).

Ukuran perusahaan (Firm Size) merupakan menggambarkan besar kecilnya suatu perusahaan yang ditunjukkan pada total aktiva, jumlah penjualan, rata-rata penjualan dan total aktiva.

Ukuran perusahaan atau firm size cenderung mencerminkan penilaian pemegang saham atas keseluruhan aspek dari financial performance di masa lampau dan perkiraan di masa yang akan datang. Semakin besarnya asset perusahaan akan membuat perusahaan memiliki kestabilan dalam kondisi keuangannya sehingga akan lebih mudah dalam memperoleh modal dibandingkan dengan perusahaan yang memiliki aset yang lebih rendah.

Ukuran perusahaan tergambar dalam signaling theory yang membahas tentang naik turunnya harga di pasar seperti harga saham, 
Printed ISSN : $2406-7415$

Electronic ISSN : 2655 - 9919

DOI: http://dx.doi.org/10.35137/jabk.v8i2.539

obligasi, dan sebagainya, sehingga akan memberi pengaruh pada keputusan investor. Tanggapan para investor terhadap sinyal positif dan negatif adalah sangat mempengaruhi kondisi pasar, mereka akan bereaksi seperti wait and see atau tunggu dan lihat dulu perkembangan yang ada baru kemudian mengambil tindakan (Fahmi 2014).

Ukuran perusahaan sangat bergantung pada besar kecilnya suatu perusahaan yang juga berpengaruh terhadap struktur modal dan sangat berkaitan dengan kemampuan perusahaan dalam memperoleh pinjaman. Perusahaan besar dinilai lebih mudah mendapatkan pinjaman karena nilai aset yang dijadikan jaminan lebih besar dan tingkat kepercayaan bank lebih tinggi dibandingkan dengan perusahaan yang kecil.

Menurut Halim (2015) semakin besar ukuran suatu perusahaan, maka kecenderungan menggunakan modal asing juga semakin besar. Hal ini disebabkan karena perusahaan besar membutuhkan dana yang besar pula untuk menunjang operasionalnya, dan salah satu alternatif pemenuhnya adalah dengan modal asing apabila modal sendiri tidak mencukupi.

Menurut Taliyang (2011) secara matematis Firm Size dapat dirumuskan sebagai berikut:

Firm Size $=$ Ln $($ Total Asset $)$

Keterangan:

$\begin{array}{ll}\text { Firm Size } & =\text { Ukuran perusahaan } \\ \text { Ln } & =\text { Logaritma } \\ \text { Total asset } & =\text { Jumlah asset }\end{array}$

\section{Sales Growth}

Tingkat pertumbuhan penjualan menunjukkan tingkat perubahan penjualan dari tahun ke tahun. Semakin tinggi tingkat pertumbuhannya, suatu perusahaan akan lebih banyak mengandalkan pada modal eksternal.

Menurut Brigham dan Houston (dalam Mahapsari dan Taman 2013) sebuah
Jurnal Akuntansi dan Bisnis Krisnadwipayana Volume 8 No. 2 (Mei - Agustus) 2021 perusahaan yang penjualannya relatif stabil akan aman dalam mengambil lebih banyak hutang dan menanggung beban tetap yang lebih tinggi daripada perusahaan yang penjualannya tidak stabil. Peningkatan penjualan dapat meningkatkan kemampuan perusahaan untuk memperoleh pendapatan dan laba perusahaan. Dengan peningkatan penjualan tersebut, maka perusahaan dapat menutup biaya-biaya yang dikeluarkan untuk operasional perusahaan, dan memperbaiki struktur modal perusahaan karena perusahaan dapat membayar hutangnya dan dapat meningkatkan modal sendiri. Pertumbuhan penjualan memiliki pengaruh yang berlawanan arah dengan saham. Semakin tinggi tingkat pertumbuhan penjualan akan memerlukan modal kerja dan modal untuk investasi, sehingga harga saham akan turun.

Sales Growth (pertumbuhan penjualan) mencerminkan keberhasilan investasi periode masa lalu dan dapat dijadikan sebagai prediksi pertumbuhan masa yang akan datang.Pertumbuhan penjualan merupakan indikator permintaan dan daya saing perusahaan dalam suatu industri. Laju pertumbuhan suatu perusahaan akan mempengaruhi kemampuan mempertahankan keuntungan dalam menandai kesempatankesempatan pada masa yang akan datang. Pertumbuhan penjualan tinggi, maka akan mencerminkan pendapatan meningkat sehingga pembayaran deviden cenderung meningkat.

Secara keuangan tingkat pertumbuhan dapat ditentukan dengan mendasarkan pada kemampuan keuangan perusahaan. Tingkat pertumbuhan yang ditentukan dengan hanya melihat kemampuan keuangan dapat dibedakan menjadi dua, yaitu tingkat pertumbuhan atas kekuatan sendiri dan tingkat pertumbuhan berkesinambungan. Tingkat pertumbuhan atas kekuatan sendiri merupakan tingkat pertumbuhan maksimum yang dapat dicapai perusahaan tanpa membutuhkan dana eksternal atau tingkat pertumbuhan yang hanya dipicu oleh tambahan atau laba dilahan, tingkat 
DOI: http://dx.doi.org/10.35137/jabk.v8i2.539

pertumbuhan berkesinambungan adalah tingkat pertumbuhan maksimum yang dapat dicapai perusahaan tanpa melakukan pembiayaan modal tetapi dengan memelihara perbandingan antara hutang dengan modal.

Swastha dan Handoko (2010) berpendapat bahwa pertumbuhan atas penjualan merupakan indikator penting dari penerimaan pasar dari produk dana atau jasa perusahaan tersebut, dimana pendapatan yang dihasilkan dari penjualan akan dapat digunakan untuk mengukur tingkat pertumbuhan penjualan. Berkaitan dengan pertumbuhan penjualan, perusahaan harus mempunyai strategi yang tepat agar dapat memenangkan pasar dengan menarik konsumen agar selalu memilih produknya, untuk itu faktor-faktor yang mempengaruhi penjualan harus benar-benar diperhatikan. Dengan mengetahui faktor-faktor tersebut perusahaan akan dapat menetapkan kebijaksanaan untuk mengantisipasi kondisi tersebut sehingga perusahaan dapat menjual produk dalam jumlah besar dan volume penjualan akan meningkat pula. Dengan meningkatnya laba perusahaan, maka keuntungan yang diperoleh para investor akan meningkat.

Pertumbuhan penjualan mencerminkan keberhasilan investasi periode masa lalu dan dapat dijadikan sebagai prediksi pertumbuhan masa yang akan datang. Pertumbuhan penjualan juga merupakan indikator permintaan dan daya saing perusahaan dalam suatu industri. Laju pertumbuhan suatu perusahaan akan mempengaruhi kemampuan mempertahankan keuntungan dalam mendanai kesempatan-kesempatan pada masa yang akan datang (Barton, dalam Detiana 2013).

Menurut Sofyan (2013) secara matematis Sales Growth dapat dirumuskan sebagai berikut:

$$
\text { Sales Growth }=\frac{\text { Total Sales } t-T \text { otal Sales } t-1}{\text { Total Sales } t-1}
$$

Jurnal Akuntansi dan Bisnis Krisnadwipayana Volume 8 No. 2 (Mei - Agustus) 2021

Keterangan:

Sales Growth= Pertumbuhan Penjualan

Total Sales $\mathrm{t}=$ Total penjualan periode berjalan

Total Sales $\mathrm{t}-1=$ Total penjualan periode tahunlalu

Bahwa perusahaan dengan penjualan yang relatif stabil dapat lebih aman memperoleh banyak pinjaman dan menanggung beban yang lebih tinggi bila dibandingkan dengan perusahaan yang penjualannya tidak stabil. Hal ini menunjukkan bahwa tingkat penjualan darisuatu perusahaan akan mempermudah perusahaan dalam memperoleh pinjaman sehingga dapat membuat manajemen lebih leluasa dalam menentukan kebijakan struktur modal perusahaan.

\section{Dividend Payout Ratio}

Dividend payout ratio adalah persentase dari pendapatan yang akan dibayarkan kepada pemegang saham sebagai "cash dividend". Dividend payout ratio adalah perbandingan antara dividend per share dengan earning per share pada periode yang bersangkutan. Di dalam komponen dividend per share terkandung unsur dividen, sehingga apabila semakin besar dividen yang dibagikan maka semakin besar pula dividend payout rationya.

Menurut I Made Sudana (2011) secara matematis Dividend Payout Ratio dapat dirumuskan sebagai berikut:

DPR $=\frac{\text { Dividand } P \text { ar Shars }}{\text { Earrith }}$

Keterangan:

DPR

$=$ Dividend Payout

Ratio

Dividendper share $=$ Dividen kas per lembar saham

Earning Per share = Laba per saham

Dividend payout ratio merupakan presentase laba yang dibagikan kepada 
DOI: http://dx.doi.org/10.35137/jabk.v8i2.539 pemegang saham dari laba yang diperoleh perusahaan. Apabila rasio ini semakin besar, artinya perusahaan memang mengalokasikan keuntungannya untuk para pemegang sahamnya. Sebaliknya jika rasio ini makin kecil, artinya perusahaan mengalokasikan sebagian laba bersihnya untuk memenuhi kebutuhan internal perusahaan (Antara 2012).

Menurut Kurniawati, dkk (2012) dividend payout ratio digunakan untuk memprediksi perolehan return bagi investor, artinya bahwa semakin besar dividen yang dibagikan oleh perusahaan atau emiten maka saham perusahaan akan semakin diminati oleh investor.Menurut Suhadak dan Raden (2015) perusahaan yang memperolah laba yang besar, maka secara teoritis perusahaan akan mampu membagikan dividen yang makin besar. Meningkatnya kemampuan perusahaan menghasilkan laba, maka perusahaan akan mampu membagikan dividen kepada pemegang saham sehingga semakin besar dividen yang akan dibagikan. Hal ini akan menyebabkan harga saham akan meningkat. Berdasarkan hal tersebut menyebabkan banyak investor yang tertarik untuk membeli saham perusahaan yang memiliki kemampuan yang tinggi dalam menghasilkan laba (Suhadak dan Raden 2015).

Demikian dapatlah dikatakan bahwa makin tingginya "dividend payout ratio" yang ditetapkan oleh suatu perusahaan, makin kecil dana yang tersedia untuk ditanamkan kembali di dalam perusahaan yang ini berarti akan menghambat pertumbuhan perusahaan. Salah satu fungsi yang terpenting dari financial manager adalah menetapkan alokasi dari keuntungan neto sesudah pajak atau pendapatan untuk pembayaran dividen di satu pihak dan untuk laba ditahan di lain pihak, di mana keputusan tersebut mempunyai pengaruh yang menentukan terhadap nilai dari perusahaan (the value of the firm).
Jurnal Akuntansi dan Bisnis Krisnadwipayana Volume 8 No. 2 (Mei - Agustus) 2021

\section{Kerangka Pemikiran}

Berdasarkan penjelasan diatas maka dibuatlah kerangka pemikiran dibawah ini yang akan digunakan dalam penelitian :

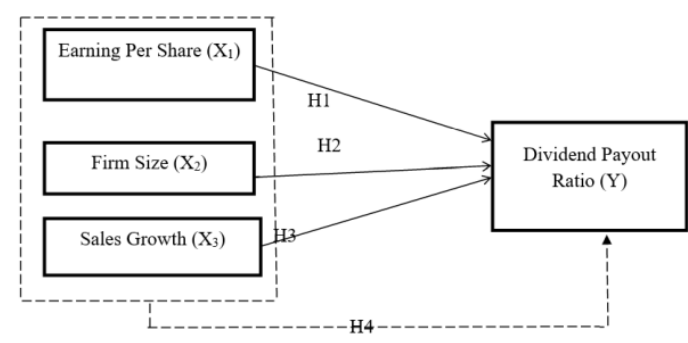

Sumber: (data diolah oleh peneliti)

Keterangan:

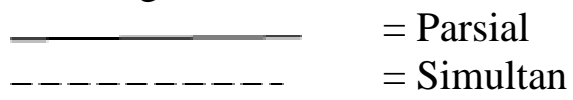

Gambar 2. Kerangka Pemikiran

Hipotesis berfungsi sebagai pegangansementara atau jawaban sementara yang masihharus dibuktikan kebenarannya di dalamkenyataan (empirical verification), percobaan(experimentation) atau praktik (implementation).

Hipotesis yang diajukan dalam penelitian ini adalah sebagai berikut:

1. H1 : Adanya pengaruh yang signifikan antara Earning Per Share terhadap Dividend Payout Ratio

2. $\mathrm{H} 2$ : Adanya pengaruh yang signifikan antara Firm Size terhadap Dividend Payout Ratio

3. H3 : Adanya pengaruh yang signifikan antara Sales Growth terhadap Dividend Payout Ratio

4. H4 : Adanya pengaruh secara simultan antara Earning Per Share, Firm Size, dan Sales Growth terhadap Dividend Payout Ratio 


\section{METODE PENELITIAN}

Jenis penelitian ini merupakan metode kuantitatif, karena data yang digunakan adalah berupa angka. Dari angka yang diperoleh tersebut digunakan dalam analisis data. Penelitian ini terdiri dari 3 (tiga) variabel yaitu Dividend Payout Ratio (DPR) sebagai variabel dependen, Earning Per Share, Firm Size, dan Sales Growth sebagai variabel independen.

Penelitian ini menggunakan data sekunder yaitu laporan keuangan tahunan setiap Perusahaan Manufaktur Sektor Makanan dan Minuman yang terdaftar di Bursa Efek Indonesia (Tahun 2014 Sampai Tahun 2018).

Metode pengumpulan data adalah menggunakan teknik dokumentasi dengan cara mengambil data laporan keuangan tahunan sektor Makanan dan Minuman yang terdaftar di Bursa Efek Indonesia (Tahun 2014 Sampai Tahun 2018).

Dalam menentukan sampel penelitian ini menggunakan purposive sampel, yaitu sampel dipilih berdasarkan tujuan penelitian.Adapun kriteria yang digunakan dalam pemilihan sampel pada penelitian ini adalah sebagai berikut: (1) Perusahaan manufaktur sektor makanan dan minuman yang terdaftar di Bursa Efek Indonesia dari periode 2014-2018.(2) Perusahaan manufaktur sektor makanan dan minuman yang menerbitkan laporan keuangan tahunan secara lengkap pada periode 20142018.(3)Perusahaan sektor manufaktur sektor makanan dan minuman yang terdaftardi Bursa Efek Indonesia periode 2014-2018 yang membagikan keuntungan berupa dividen kepada para pemegang saham.

Teknik analisis dataantara lain: (1) Uji Asumsi Klasik yaitu terdiri dariuji normalitas,ujimultikolinearitas,uji

heteroskedastisitas, dan autokorelasi data. (2)Uji Kelayakan Model(UjiF). (3) Uji Signifikan Parsial (Uji t) (4) Koefisien Determinasi ( $\mathrm{R}^{2}$ ). (5) Analisis Regresi Linear

\section{HASIL PENELITIAN DAN PEMBAHASAN}

\section{Hasil Penelitian}

\section{Uji Asumsi klasik}

Hasil uji normalitas menggunakan uji Kolmogorov Smirnov adalah 0,119 dan signifikansi pada 0,200yang menandakan bahwa nilai tersebut lebih besar dari 0,05 , sehingga dapat disimpulkan bahwa data residual berdistribusi normal.

Hasil uji autokorelasi nilai dU hitung pada penelitian ini adalah 1.653 dan nilai dL 1.283. maka diperoleh nilai Durbin-Watsonhitung 0,522 , nilai ini akan dibandingkan dengan tabel Durbin-Watson dengan jumlah observasi $(\mathrm{n})=$ 35 , jumlah variabel independen $(\mathrm{k})=3$ dan tingkat signifikansi 0,05 di dapat nilai $\mathrm{dl}=1.283$ dan nilai $d u=1.653$. Oleh karena DurbinWatson 0,522 berada di bawah $\mathrm{dl}=1.283$ dan di atas 0 , maka dari tabel keputusan $\mathrm{H} 0$ yang menyatakan tidak ada autokorelasi positif ditolak, yang berarti terdapat autokorelasi positif.

Hasil uji multikolonearitasmenghasilkan perhitungannilai tolerance dari masing-masing variabel independen lebih besar dari 0,10, yaitu untuk variabel Earning Per Share sebesar 0,264, variabel Firm Size sebesar 0,203, dan variabel Sales Growth sebesar 0,175yang berarti tidak ada korelasi antara variabel independen.

Sedangkan Nilai dari hasil valance inflation faktor(VIF) dari masing-masing variabel independen diketahui kurang dari 10, yaitu untuk variabel Earning Per Share sebesar 3,783, variabel Firm Size sebesar 4,926, dan variabel Sales Growth sebesar 5,706.Jadi dari penjelasan tersebut dapat disimpulkan bahwa 
DOI: http://dx.doi.org/10.35137/jabk.v8i2.539

tidak ada multikolonieritas antara variabel independen dalam model regresi.

Hasil uji heteroskedastisitas dari grafik scatterplots pada kinerja keuangan pada terlihat bahwa titik - titik menyebar secara acak serta tersebar diatas dan dibawah angka 0 pada sumbu Y sehingga dapat disimpulkan bahwa tidakterjadi masalah heteroskedastisitas, hingga model regresi yang baik dan ideal dapat terpenuhi.

\section{Uji Kelayakan Model (Uji F)}

Hasil Uji Linearitas,ada hubungan linear secara signifikan antara variabel Earning Per Share (X1) dengan variabel Dividend Payout Ratio (Y), ada hubungan linear secara signifikan antara variabel Firm Size (X2) dengan variabel Dividend Payout Ratio (Y), dan ada hubungan linear secara signifikan antara variabel Sales Growth (X3) dengan variabel Dividend Payout Ratio (Y).

Hasil penghitungan koefisien regresi sederhana memperlihatkan Arah hubungan antara variabel bebas (Earning Per Share) dengan variabel terikat (Dividend PayoutRatio) adalah searah, dimana setiap kenaikan satu satuan variabel Earning Per Share akan akan menyebabkan kenaikan Dividend Payout Ratio sebesar 299,195.Arah hubungan antara variabel bebas (Firm Size) dengan variabel terikat (Dividend Payout Ratio) adalah searah, dimana setiap kenaikan satu satuan variabel Firm Size akan akan menyebabkan kenaikan Dividend PayoutRatio sebesar 825,633. Arah hubungan antara variabel bebas (Firm Size) dengan variabel terikat (Dividend Payout Ratio) adalah searah, dimana setiap kenaikan satu satuan variabel Firm Size akan akan menyebabkan kenaikan Dividend Payout Ratio sebesar 825,633.Arah hubungan antara variabel bebas (Sales Growth) dengan variabel terikat (Dividend Payout Ratio) adalah searah, dimana setiap kenaikan satu satuan variabel Firm Size akan akan menyebabkan kenaikan Dividend Payout Ratio sebesar 67309,731.
Jurnal Akuntansi dan Bisnis Krisnadwipayana Volume 8 No. 2 (Mei - Agustus) 2021

\section{Koefisien Determinasi $\left(\mathbf{R}^{2}\right)$}

Koefisien korelasi Pearson product moment Dividend Payout Ratio sebesar $.500^{* *}$. Artinya besar korelasi atau hubungan antara variabel Earning Per Share, Firm Size, dan Sales Growth ialah sebesar 0,500 atau sedang karena mendekati angka 1.

Koefisien Determinasi, nilai adjusted $\mathrm{R}$ square sebesar 0,745 yang berarti bahwa 74,5\% variabel dependen (Dividend Payout Ratio) dapat dijelaskan oleh ketiga variabel independen (Earning Per Share, Firm Size, dan Sales Growth). Sedangkan sisanya 25,5\% dapat dijelaskan oleh faktor lain yang tidak diteliti dalam penelitian ini.

\section{Analisis Regresi LinearBerganda}

Analisis Regresi Linier Berganda, diperoleh persamaan regresi linier berganda sebagai berikut:

$\mathrm{Y}=39163,313+-40,734 \mathrm{X} 1+-2333,504 \mathrm{X} 2+$ 163331,820 X3

1) Nilai Konstanta (a) adalah 39163,313. Besaran konstanta menunjukkan bahwa jika variabel-variabel independen (Earning Per Share, Firm Size, dan Sales Growth) diasumsikan konstan, maka variabel dependen (Dividend Payout Ratio) sebesar 39163,313.

2) Nilai koefisien regresi variabel earning per share yang bernilai-40,734. Hal ini dapat diartikan bahwa setiap kenaikan earning per share sebesar $1 \%$ maka dividend payout ratio meningkat $-40,734$ (dengan asumsi variabel lain nilainya tetap).

3) Nilai koefisien regresi variabel firm size yang bernilai -2333,504. Hal ini menunjukkan bahwa setiap peningkatan firm size sebesar $1 \%$ maka dividend payout ratio meningkat -2333,504 (dengan asumsi variabel lain nilainya tetap).

4) Nilai koefisien regresi variabel sales growth yang bernilai 163331,820. Hal ini menunjukkan bahwa setiap peningkatan 
DOI: http://dx.doi.org/10.35137/jabk.v8i2.539 sales growth sebesar 1\% maka dividend payout ratio meningkat sebesar 163331,820 (dengan asumsi variabel lain nilainya tetap).

\section{Uji Signifikansi Parsial (Uji t)}

Berikut ini adalah tabel hasil pengujian secara parsial sebagai berikut:

1) Hipotesis 1: Earning Per Share berpengaruh negatif terhadap Dividend Payout Ratio

Berdasarkan hasil uji signifikan parsial nilai uji t hitung earning per share sebesar 0,404 dengan tingkat signifikan 0,689. Sehingga disimpulkan bahwa $\mathrm{H} 1$ ditolak, artinya secara parsial bahwa variabel earning per share tidak berpengaruh terhadap dividend payout ratio.

2) Hipotesis 2: Firm Size berpengaruh positif terhadap Dividend Payout Ratio

Berdasarkan hasil uji signifikan parsial nilai uji t hitung firm size sebesar -5,609 dengan tingkat signifikan 0,000 . Sehingga disimpulkan bahwa $\mathrm{H} 2$ diterima, artinya secara parsial bahwa variabel firm size berpengaruh positif terhadap dividend payout ratio.

3) Hipotesis 3: Sales Growth berpengaruh positif terhadap Dividend Payout Ratio

Berdasarkan hasil uji signifikan parsial nilai uji t hitung sales growth sebesar 8,297 dengan tingkat signifikan 0,000 . Sehingga disimpulkan bahwa $\mathrm{H} 3$ diterima, artinya secara parsial bahwa variabel sales growth berpengaruh positif terhadap dividend payout ratio.

Uji Signifikansi Simultan (Uji F), nilai F sebesar 34,169 dengan nilai probabilitas sebesar $0,000<0,05$. Hal ini dapat disimpulkan bahwa earning per share, firm size, dan sales growth secara simultan atau bersama-sama berpengaruh signifikan terhadap dividend payout ratio.
Jurnal Akuntansi dan Bisnis Krisnadwipayana Volume 8 No. 2 (Mei - Agustus) 2021

\section{Pembahasan}

1. Earning Per Share berpengaruh negatif terhadap Dividend Payout Ratio

Hasil penelitian ini menunjukkan bahwa Earning Per Share (X1) terdapat pengaruh negatif dan tidak signifikan terhadap Dividend Payout Ratio (Y), Penelitian ini memperkuat penelitian yang dikatakan Dr. Aurangzeb (2012), yang mengatakan bahwa Earning Management berpengaruh negatif terhadap Dividend Payout Ratio.

2. Firm Size Berpengaruh Positif terhadap Dividend Payout Ratio

Penelitian ini memperkuat penelitian Purweni Widhianningrum (2013), mengatakan Firm Size (ukuran perusahaan) mampu mendorong dividend payout ratio yang tinggi. Sehingga menunjukkan bahwa secara parsial Firm Size berpengaruh signifikan terhadap Dividend Payout Ratio.

3. Sales Growth Berpengaruh Positif terhadap Dividend Payout Ratio

Dengan demikian dapat dikatakan bahwa Sales Growth berpengaruh positif dan signifikan terhadap Dividend Payout Ratio.

4. Earning Per Share, Firm Size, dan Sales Growth secara bersama-sama Berpengaruh Positif Terhadap Dividend Payout Ratio

Berdasarkan hasil uji F, dapat diketahui secara simultan earning per share, firm size, dan sales growth memiliki pengaruh signifikan terhadap dividend payout ratio pada perusahaan manufaktur sektor makanan dan minuman selama periode 2014-2018. Berdasarkan uji $\mathrm{F}$ bahwa nilai $\mathrm{F}$ hitung sebesar 34,169 dengan nilai probabilitas sebesar $0,000<0,05$. Hal ini dapat disimpulkan bahwa earning per share, firm size, dan sales growth secara simultan atau bersama-sama berpengaruh 
DOI: http://dx.doi.org/10.35137/jabk.v8i2.539 signifikan terhadap dividend payout ratio.

\section{KESIMPULAN DAN SARAN}

\section{Kesimpulan}

Berdasarkan analisis dan pembahasan diatas maka dapat ditarik kesimpulan yaitu : (1).Earning Per Share memiliki pengaruh negatif dan tidak signifikan terhadap Dividend Payout Ratio (2).Firm Size memiliki pengaruh positif terhadap Dividend Payout Ratio (3).Sales Growth memiliki pengaruh positif terhadap Dividend Payout Ratio. (4).Variabel Earning Per Share, Firm Size, dan Sales Growth secara simultan atau bersama-sama berpengaruh signifikan terhadap Dividend Payout Ratio.

\section{Saran}

Bagi Investor jika ingin memaksimalkan pembayaran Dividend Payout Ratio kepada pemegang saham diharapkan dapat fokus pada dua variable yang berpengaruh terhadap Dividend Payout Ratio secara signifikan yaitu Firm Size dan Sales Growth,

Bagi Peneliti Selanjutnya, disarankan agar mengikutsertakan variabel lain yang masih relevan dengan penelitian, seperti Cash Position, Asset Growth, dan Return On Asset dan memperluas sektor penelitian tidak hanya di sektor Makanan dan Minuman serta dapat menggunakan sampel yang lebih banyak. Sehingga diharapkan akan memperoleh kesimpulan yang lebih baik.

\section{DAFTAR PUSTAKA}

Agus, Sartono. 2011. Manajemen Keuangan Teori dan Aplikasi. Yogyakarta: BPFE.
Printed ISSN : $2406-7415$

Electronic ISSN : 2655 - 9919

Jurnal Akuntansi dan Bisnis Krisnadwipayana Volume 8 No. 2 (Mei - Agustus) 2021

Astuti, M. 2018. Pengaruh Sales Growth Dan Profitabilitas Terhadap Dividen Payout Ratio Pada Perusahaan Perbankan Yang Terdaftar Di Bursa Efek Indonesia. I-ECONOMICS: $A$ Research Journal on Islamic Economics, 4(1), 112-124. https://doi.org/10.19109/ieconomics .$v 4 i 1.2280$

Bambang Riyanto. 2013. Dasar-Dasar Pembelanjaan Perusahaan. Edisi Keempat. BPFE-Yogyakarta. Yogyakarta.

Basu Swastha, Hani Handoko. 2011. Manajemen Pemasaran-Analisis Perilaku. Konsumen. Yogyakarta: BPFE.

Brigham, Eugene F. Dan J.F. Houston. 2010. Dasar-Dasar Manajemen Keuangan. Edisi 11. Jakarta: Salemba Empat.

Daft Richard \& Marcic. 2013. Manajemen. Jakarta: Salemba Empat.

Darmadji., Tjiptono., \& Fakhruddin. 2012. Pasar Modal Di Indonesia. Edisi Ketiga. Jakarta: Salemba Empat.

Daryanti, L. 2016. Pengaruh Capital Expenditure, Investment Opportunity Set, Pertumbuhan Perusahaan, dan Struktur Modal Terhadap Dividend Payout Ratio. 2(3), 41-53.

Di, T., \& Periode, B. E. I. 2019. Pengaruh Debt Equity Ratio (DER), Return On Asset (ROA), Cash Position (CASH), Asset Growth (GROWTH) Terhadap Dividend Payout Ratio Pada Perusahaan Manufaktur Sub Sektor Food And Beverage. 22(1), 46-60.

Dilawer, T., Sinabutar, A., \& Nugroho, A. B. 2012. Earning Management and 
DOI: http://dx.doi.org/10.35137/jabk.v8i2.539

Dividend Policy: Evidence from

Pakistani.Journal of Business and Management, 4(4), 453-464.

Fahmi, Irham. 2012. Analisis Laporan Keuangan. Cetakan Ke-2. Bandung: Alfabeta

Ghozali, Imam. 2011. "Aplikasi Analisis Multivariate Dengan Program SPSS". Semarang: Badan Penerbit Universitas Diponegoro.

Gitman, Lawrence J. 2012. Principles of Managerial Finance. Eleventh Edition. United StatesMilitary Academy, West Point: McGrawHillhigher Education, hal. 290.

Hanif, M., \& Bustaman. 2017. Pengaruh Debt to Equity Ratio, Return On Asset, Firm Size dan Earning Pe Share Terhadap Dividend Payout Ratio.Jurnal Ilmiah Mahasiswa Ekonomi Akuntansi, 2(1), 73-81.

Harahap, Sofyan Syafri. 2013. Analisis Kritis Atas Laporan Keuangan. Cetakan Kesebelas. Penerbit Rajawali Pers, Jakarta.

Hidayat, S. F. 2012. Analisis pengaruh rasio keuangan dan rasio non keuangan terhadap kebijakan.Naskah Publikasi Universitas Muhammadiyah Surakarta.

Hikmah, Khoirul. 2010. Analisis FaktorFaktor yang Mempengaruhi Kebijakan Dividen: Pendekatan Teori Stakeholder.Jurnal Kharisma, 4(2): 91-105.

Irin Arian Wardani, Isharijadi, E. A. 2018. Pengaruh Current Ratio dan Debt to Equity Ratio Terhadap Dividend Payout Ratio Perusahaan Manufaktur BEI.
Printed ISSN : $2406-7415$

Electronic ISSN : 2655 - 9919

Jurnal Akuntansi dan Bisnis Krisnadwipayana Volume 8 No. 2 (Mei - Agustus) 2021

Jatmika, D., \& Andarwati, M. 2018. Pengaruh Kinerja Keuangan Yang Diukur Dengan Rasio Rentabilitas Terhadap Dividend Payout Ratio.Jurnal Ilmiah Ekonomi Islam, 4(01), 41-50.

Jurica Lucyanda, L. 2018. Pengaruh Free Cash Flow dan Struktur Kepemilikan Terhadap Dividend Payout Ratio. Jurnal Dinamika Akuntansi, 4, 129138.http://journal.unnes.ac.id/nju/in dex.php/jda.

Kasmir. 2016. Analisis Laporan Keuangan. Jakarta: Raja Grafindo Persada.

Kevin, N. A. N. S., \& Thomas Firdaus Hutahean, S. T. G. 2019. Pengaruh Free Cash Flow, Leverage, Net Profit Margin dan Pertumbuhan Perusahaan Terhadap Dividend Payout Ratip Perusahaan Property Real and Estate Yang Terdaftar Di Bursa Efek Indonesia.Journal of Economic, Business and Accounting, 2 nomor 2, 363-371. https://doi.org/10.31539/costing.v2i 2.672 .

Khan, W., \&Ashraf, N. 2014. In Pakistani Service Industry: Dividend Payout Ratio as Function of some Factors.International Journal of Academic Research in Accounting, Finance and Management Sciences, 4(1), 390-396. https://doi.org/10.6007/ijarafms/v4il/696.

Kowanda, D., \& Sari, D. I. 2016. Dividend Payout Ratio Pada Emiten Manufaktur. 31-46.

Lasmaria Tampubolon, Marina, Jois fitri situmorang, H. 2019. Pengaruh Debt to Equity Ratio, Current Ratio, Net 
DOI: http://dx.doi.org/10.35137/jabk.v8i2.539

Profit Margin Terhadap Dividend Payout Ratio Pada Sektor Perdagangan, Jasa dan Investasi.Aksara Public, 3, 172-177.

Mahaputra, G., \& Wirawati, N. 2014. Pengaruh Faktor Keuangan Dan Ukuran Perusahaan Pada Dividend Payout Ratio Perusahaan Perbankan.E-Jurnal Akuntansi, 9(3), 695-708.

Mahendra Yasa, K., \& Wirawati, N. 2016. Pengaruh Net Profit Margin, Current Ratio, Dan Debt To Equity Ratio Pada Dividend Payout Ratio.EJurnal Akuntansi, 16(2), 921-950.

Mehta, A. 2012. An Empirical Analysis of Determinants of Dividend Policy Evidence from the UAE Companies. Global Review of Accounting and Finance, 3(1), 18-31.

Munawir, S. 2010. Analisis Laporan Keuangan Edisi keempat. Cetakan Kelima Belas. Yogyakarta: Liberty.

Parera, D. 2016. Pengaruh Net Profit Margin (Npm), Return on Asset (Roa), Dan Debt To Equity Ratio (Der) Terhadap Dividend Payout Ratio ( Dpr ) Pada Perusahaan Yang Tercatat Dalam Indeks Lq45 Di Bei Periode 2009-2013. Jurnal EMBA, 4(2), 538-548.

Peraturan Otoritas Jasa Keuangan Nomor 53/POJK.04/2017., Tentang klasifikasi perusahaan asset skala kecil dan menengah, termasuk batasan pendanaan modal perusahaan. Jakarta: Otoritas Jasa Keuangan

Perusahaan, P. U., Sari, E. S., Fakultas, D., Universitas, E., \& Bengkulu, D. 2011. Pertumbuhan Perusahaan, dan Kepemilikan Institusional
Printed ISSN : $2406-7415$

Electronic ISSN : 2655 - 9919

Jurnal Akuntansi dan Bisnis Krisnadwipayana Volume 8 No. 2 (Mei - Agustus) 2021 Terhadap Kebijakan Dividend Payout Ratio (DPR). 231-242.

Perwira, H., \& Ratnaningsih, D. 2017. Analisis Pengaruh Struktur Kepemilikan dan Struktur Dewan Komisaris Independen terhadap Dividend Payout Ratio.Jurnal Universitas Atma Jaya Yogyakarta, 31(1), 1-15.

Puspita, E. 2017. Pengaruh Likuiditas, Profitabilitas, Leverage, dan Market Ratio terhadap Dividend Payout Ratio pada Perusahaan Manufaktur. 1, 17-35.

Romanian, T., Journal, E., \& Imran, K. 2011. Determinants of Dividend Payout Policy: A Case of Pakistan Engineering Sector.The Romanian Economic Journal, 14(41), 47-60.

Rudianto. 2012. Pengantar Akuntansi Konsep \& Teknik Penyusunan Laporan Keuangan. Penerbit: Erlangga, Jakarta, hal. 290.

Silalahi, Ulber. 2012. Metode Penelitian Sosial. Bandung: Refika Aditama, hal. 336.

Simanjuntak, S. M. 2016. Pengaruh Return On Asset, Growth, Total Asset Turnover, Ownership, Firm Size Dan Debt To Total Asset Terhadap Dividend Payout Ratio Pada Perusahaan Yang Terdaftar Di Bursa Efek Indonesia.Jurnal Lentera Akuntansi, 2(2), 101-116.

Sinabutar, A., \& Nugroho, A. B. 2015. Dividend Payout Ratio in Indonesian Consumer Goods Industry: Panel Analysis and Determinant Factors in 20042013.Journal of Business and Management, 4(4), 453-464. 
Sudana, I Made. 2011. Manajemen Volume 8 No. 2 (Mei - Agustus) 2021

Keuangan Perusahaan Teori dan Praktek. Jakarta: Erlangga.

Sugiyono. 2014. Metode Penelitian Pendidikan Pendekatan Kuantitatif, Kualitatif, dan $R \& D$. Bandung.

Sulhan, M., \& Nurillah, S. 2018. Dampak Struktur Kepemilikan Dan Profitabilitas Terhadap Kebijakan Hutang Dengan Kebijakan Deviden Sebagai Variabel Pemoderasi (Studi Pada Sektor Properti, Real Estate Dan Konstruksi Bangunan Yang Terdaftar Dibei). Manajemen, Akuntansi Dan Perbankan, 46, 794807.

Taliyang, S. M., Latif, R. A., dan Mustafa, N. H. 2011. The Determinants of Intellectual Capital Disclosure Among Malaysian Listed Companies. International Journal of Knowledge Management. Vol. 4, No. 3, Hal: 25-33.

Tandelilin, Eduardus. 2010. Portofolio dan Investasi Teori dan Aplikasi. Edisi pertama. Yogyakarta: Kanisius.

Widhianingrum, P. 2013. Pengaruh Biaya Agensi, Kesempatan Investasi, Hutang, Likuiditas, Profitabilitas, Dan Ukuran Perusahaan Terhadap Dividend Payout Ratio. Jurnal Akuntansi Dan Pendidikan, 2(1), 1. https://doi.org/10.25273/jap.v2i1.57 1

Wijayanto, E., \& Putri, A. N. 2018. Analisis Pengaruh Rasio Likuiditas, Rasio Leverage, Rasio Profitabilitas Dan Kepemilikan Manajerial Terhadap Kebijakan Dividen.Jurnal Aktual Akuntansi Keuangan Bisnis, 1(2), 105-118.

www.idx.co.id 
Printed ISSN : $2406-7415$

Electronic ISSN : 2655 - 9919

DOI: http://dx.doi.org/10.35137/jabk.v8i2.539

Jurnal Akuntansi dan Bisnis Krisnadwipayana Volume 8 No. 2 (Mei - Agustus) 2021

Copyright (c) 2021 Siti Nur Latifah, SE., M.Si.

\section{(C) 100}

